\author{
素粉末混合法による Ti-6Al-4V 合金の焼結・鍛造特性

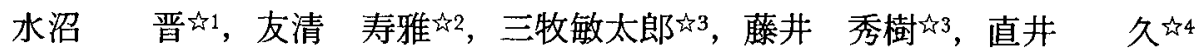

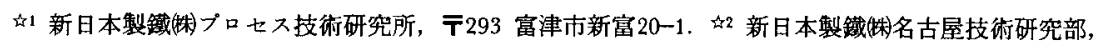

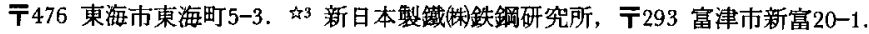 \\ 出4 日鐵テクノリサーチ秼，广宁293 富津市新富20-1.
}

\title{
Sintering and Forging Characteristics of Sintered Ti-6Al-4V Alloy Produced by Blended Elemental Method
}

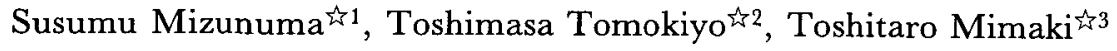 \\ Hideki Fujii ${ }^{\Uparrow 3}$ and Hisashi Naoi ${ }^{\Uparrow 4}$

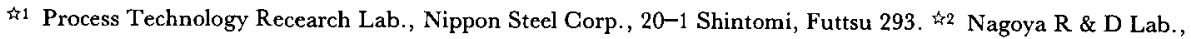

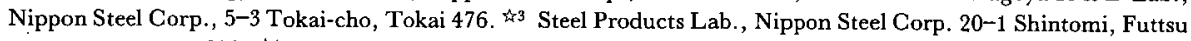 \\ 293. ${ }^{4}$ Nippon Steel Techno Research Corp., 20-1 Shintomi, Futtsu 293.
}

Received December 28, 1995

\section{SYNOPSIS}

In the process of production of Ti-6Al-4V alloy, which consists of blending of extra-low-chlorine $\mathrm{Ti}$ and 60mass\%Al-40mass\%V master alloy, cold compaction, vacuum sintering and hot forging, the influence of compaction stress and sintering conditions on the density of sintered compacts and various forging characteristics of the sintered compacts were investigated.

The increasing rate of the compact density during heating up to sintering temperature depends on density of the green compact and heating time, with which it has a linear correlation. The increasing rate of the compact density during holding at sintering temperature is in proportion to the power of the holding time. The empirical equation of the density change during sintering was derived from these findings, and confirmed to coincide well with experimental values.

The density after forging is strongly influenced by pressure and plastic deformation during forging. The holes in the compact can be rejected completely by suitable forging condition, except the surface area of the compact where the temperature reduces rapidly compared with that of the inner part of the compact.

KEYWORDS

titanium alloy, extra low chlorine Ti powder, master alloy, Ti-6Al-4V alloy, CIP, cold compaction, vacuum sintering, density, forging

\section{1 緒言}

チタン合金は比強度が高く, 耐熱性, 耐食性に優れ, 航空宇宙機器材料, 化学工業用材料などに使用されて いる゙．しかし，溶解や鐙造，切削加工などの制造コ ストが高く、これを改善するためのNear Net Shape （NNS）成形技術として粉末治金法が注目されている. 粉末冶金法の利点としては，これ以外にも偏析が少な いこと，材質の異方性が少ないこと，溶解法では製造 できない成分系の製品が製造可能であることなどがあ げられる。

チタン合金の粉末成形法には主として二種類がある。
一つは合金成分組成の粉末を使用する合金粉末法であ り，他は，純チタン㸮末と母合金㸮末を用いる素粉末 混合法である2)、3).これの標準的工程は, 通常は, 上 記混合物末をCIP (Cold Isostatic Pressing) あるい, は金型成形を用いて所定の形に圧粉成形し, 真空焼絬 処理により合金化し，さらにここの合金中に存在する 残留空陸を除去するHIP (Hot Isostat ic Pressing) 成 形などから棈成される．この方法は, 合金粉末成形法 に比して, 原料㸮が安価, 室温での成形が可能, 広範 囲の組成の合金が製造可能などの利点がある.

この㸮末混合法に関しては多くの研究がなされてい 
る. Ti-6Al-4V合金については, S.Abkowitz $\zeta^{4)}$, 萩原 $ら^{2)}$, また山崎ら ${ }^{6)}$ が成形・焼結条件が焼結体の密度 におよぼす影響について報告している，また，極低塩 素チタン粉末を使用すること，HIP技術の確立などによ り密度が $100 \%$ に達し, 溶製材なみの疲労特性をむつよ うになることを明らかにしている，さらに，組織制御 を施し金属組織を微細化すれば, 疲労特性は溶製材の データ幅の上限値以上に達することも報告されている 2). 5).

しかし, 自動車用部品など民生品に適用するにはこ れらの方法であなおコスト高である. そこで, コスト に占める割合の大きいHIP工程をより生産性の高い焼結 鍜造（粉末鍛造）で置き換えることが可能であれば都 合がよい.

媪結鍜造法はいくつかの金属についてすでに実用化 されている. 開発がむっとむ早く進んだのは, 鉄合金 でありコンロッドなど自動車用部品へ適用されている. この分野では, 最適な鉄粉の条件, 鍛造時の割れや密 度の挙動, 最適プリフォーム形状などが明らかにされ， また全自動製造設備の開発などによりほぼ製造技術が 確立していることなどが木村により解説されている77. 最近では急冷凝固アルミニウム合金す実用化されてい る.この分野では鍛造時の塑性変形により粉末表面の 酸化膜の悪影響を除く技術などが開発されている ${ }^{8)}$. しかし，チタン合金に対して焼結鐉造を適用した例は 報告されていない.

以上のような背景のむとで, 筆者らは, 粉末混合 法におけるHIP工程を焼結鍛造で圏き換えることを目的 として一連の研究を行っている. 本報告は, これらの 内で, 焼結収縮举動におよぼす各種成形・焼結条件の 影響および単純形状金型により調査した焼結鍛造特性 に関するむのである。

\section{2 成形焼結挙動および焼結密度推定式}

焼結鍜造における鐉造用素材の適正な製造条件を明 らかにするために成形焼結条件を変化させて焼結挙動 を調查した。また、鍜造用素材の寸法を正確に決める ために必要な密度推定式す同時に導出した。

\section{1 実験方法}

試験に用いた羒末はTi物と60mass\%A 1-40nass\%V母合 金㸮の混合㸮で, 混合割合はTi $: 60 \mathrm{Al}-40 \mathrm{~V}=89.5: 10.5$ と し, $\mathrm{v}$ 型混合器で 1 時間の混合を行った. Photo.1に物 末の外観写真を示した. $\mathrm{Ti}$ 粉は平均粒径 $80 \mu \mathrm{m}$ の極低

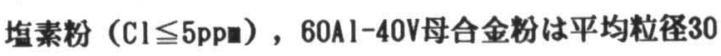
$\mu \mathrm{m}$ てある. 烧桔体の成分分析值（重量\%）は， 11 :
$6.40 \%, V: 4.21 \%, \mathrm{Fe}: 0.06 \%, 0: 0.12 \%$ ，および $\mathrm{Cl}<0.005 \%$ あった.

成形はCIP成形と片押しの金型ブレス成形により行っ た. CIP成形では内径 $20 \mathrm{~mm}$, 高さ $20 \mathrm{~mm}$, 厚さ $1 \mathrm{~mm}$ のNBR （アクリルニッルゴム）のゴム型を用い，粉末装媜後，ゴム型 を薄肉のビニル袋に真空封入 (約13.3Pa) し, 成形圧 力を $480 \mathrm{MPa}$ とした. 金型プレス成形では直径 $12 \mathrm{~mm}$ の円 柱状金型（超硬合金製）を用い，所定重量の粉末を金 型を振動させながら投入した後,プレス成形を行った。 この時, 成形圧力は294, 480MPaの2条件とし, 各成形 圧力において成形体高さが等しくなるように粉末投入 量はそれぞれ $3.3 ， 3.5 \mathrm{~g}$ とした. なお，金型澗滑は行っ ていない.

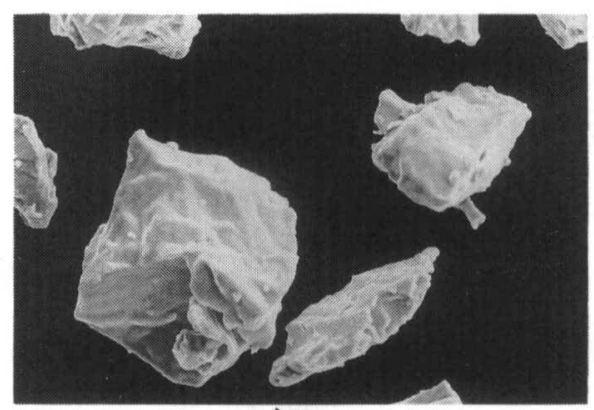

a) $\mathrm{Ti}$

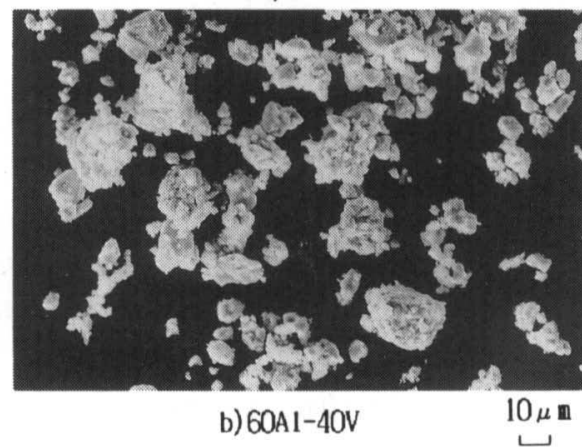

Photo. 1 Appearance of a) $\mathrm{Ti}$ and b) 60AL-40V powders used in the experiments.

真空炉により焼結を行った. 初期真空度は $1.33 \times$ $10^{-3} \mathrm{~Pa}$ である. 焼結温度は $1473,1523,1573$ Kの 3 条件, 焼結時間は3.6, 7.2, 14.4,21.6ksの 4 条件に変化さ せた. 昇温速度は $1143 \mathrm{~K}$ ま゙は $0.033 \mathrm{~K} / \mathrm{s}, 1143 \mathrm{~K}$ 以上で は0.083K/sとした.なお、1143Kまでは焼結収縮が生じ ていない，試料の密度はアルキメデス法によって測定 した.

Fig. 1に各焼結温度における焼結時間と相対密度の関 俰を示した. 金型プレスとCIPの相対密度を、成形圧力 $480 \mathrm{MPa}$ の場合について比較すると、約10\%CIPの方が高 
い. 焼結体の相対密度は各焼結温度において, 成形体 の相対密度の大きいむのほど大きくなっており，焼結 後の密度は成形体密度に依存していることがわかる. また，全ての成形圧力において相対密度は焼結時間と とあに增加している.この增加率は焼結温度が高いほ ど大きい，また，相対密度の增加率は佰温域よりも昇 温域（1143K〜焼結温度）のほうが大きく，さらに， その增加率は成形体密度の低いむのほど大きくなって いる.Photo.2にはCIP成形体に対して1523Kで焼結を 行った場合の各焼結時間における試駼片内部の組機を

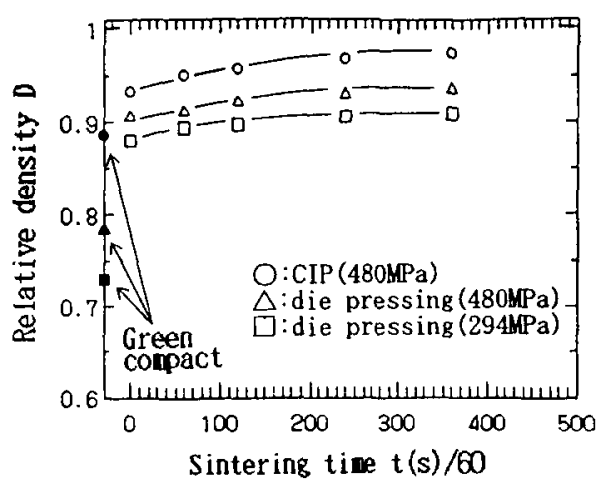

a) Sintering temperature: $1473 \mathrm{~K}$

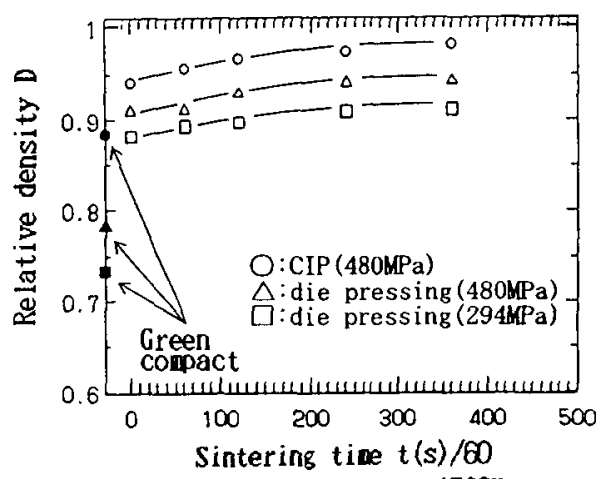

b) Sintering temperature: $1523 \mathrm{~K}$

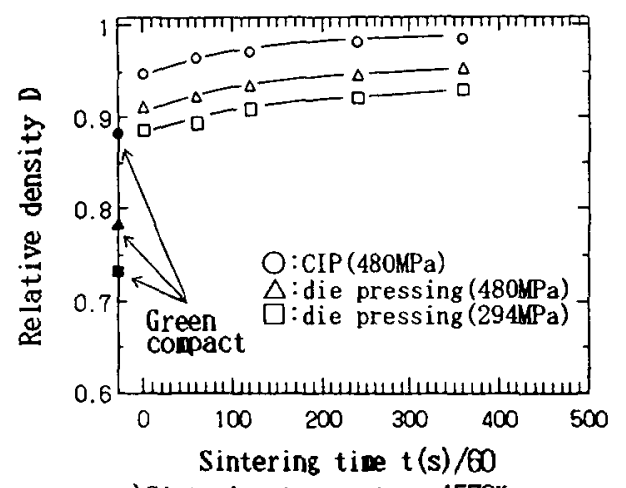

c) Sintering temperature: $1573 \mathrm{~K}$

Fig. I Influence of sintering temperature and sintering time on relative density. 示した．焼結時間0ksでは試験片内の空㗂は不定形状を 示し，その数も多い．焼結時間が長くなるとこの空陌 は球状化し，その数す少なくなってくる．しかし焼結 時間21.6ksでは空償の状態は焼結時間14.4ksの場合と 大きな違いはない.

\section{2 密度推定式（焼結収縮式）}

以上の焼結実験結果を用いて密度推定式（焼結収縮 式と等洒）の導出を行う. 従来から, 焼結収縮に関す る材料学的研究は多く行われており，応力負荷のない 単一成分系の固相焼結においては，恒温域での収縮は 以下の式で一般的に表される9．

$$
\Delta \mathrm{L} / \mathrm{L}_{\mathrm{O}}=\mathrm{K} \mathrm{t}^{\mathrm{x}}
$$

ここで, $\mathrm{L}_{0}$ : 元の長さ， $\Delta \mathrm{L}:$ 焼結による線収縮量, $\mathrm{t}$ : 焼結時間, $\mathrm{K}, \mathrm{x}$ : 定数 である.

（1）式におけるK，Xの各定数は赎結の機棈によっ て決定されている.そこで，この関係式を参考にして， 以下のように昇温域と恒温域に分けて密度推定式の導 出を行った。なお、密度推定式を焼結による相対密度 上昇率の形で表示している.

$$
\begin{gathered}
\Delta \mathrm{D} / \mathrm{D}_{0}=\Delta \mathrm{D}_{1} / \mathrm{D}_{0}+\Delta \mathrm{D}_{2} / \mathrm{D}_{0} \\
\Delta \mathrm{D}_{1} / \mathrm{D}_{0}=\mathrm{fn}\left(\mathrm{t}_{1}\right) \\
\Delta \mathrm{D}_{2} / \mathrm{D}_{0}=\mathrm{fn}\left(\mathrm{t}_{2}\right)
\end{gathered}
$$

ここで, $\Delta \mathrm{D}$ : 相対密度の変化量, $\mathrm{D}_{0}$ ：元の相対密 度 (成形体)， $\Delta D_{1}$ : 昇温域での相対密度の変化量, $\Delta \mathrm{D}_{2}$ : 佰温域での相対密度の変化量, $t_{1}$ : 昇温時間 (s), $t_{2}$ : 焼結均熱時間(s)である.

1143Kまでは焼結収縮が起こっていなかったので， 1143K以降の昇温域について, 昇温速度が0.083K/sの条 件の場合の収縮式を以下のようにして求めた.Fig.2に 示したように昇温時間と相対密度の変化量の間には直 線関保がある.また，成形圧力の低いむの，すなわち 成形体密度の低いむのほど相対密度の变化率が大きく なっている.Fig.2の直線の傾きおよび切片と成形焼結 条件の間の関係を求めることによりつぎの実験式を得 た.

$$
\begin{aligned}
\Delta_{1} / \mathrm{D}_{0}= & \left(-1.13 \times 10^{-2} \mathrm{D}_{0}+1.01 \times 10^{-2}\right) \cdot\left(\mathrm{t}_{1} / 60\right) \\
& +\left(-2.36 \times 10^{-2} \mathrm{D}_{0}+2.08 \times 10^{-2}\right)
\end{aligned}
$$

恒温域については，（1）式の関係を予測して各成 形圧力における相対密度の変化量と焼結時間の雨対数 フロットをとりFig.3に示した. 金型プレスで成形圧力 


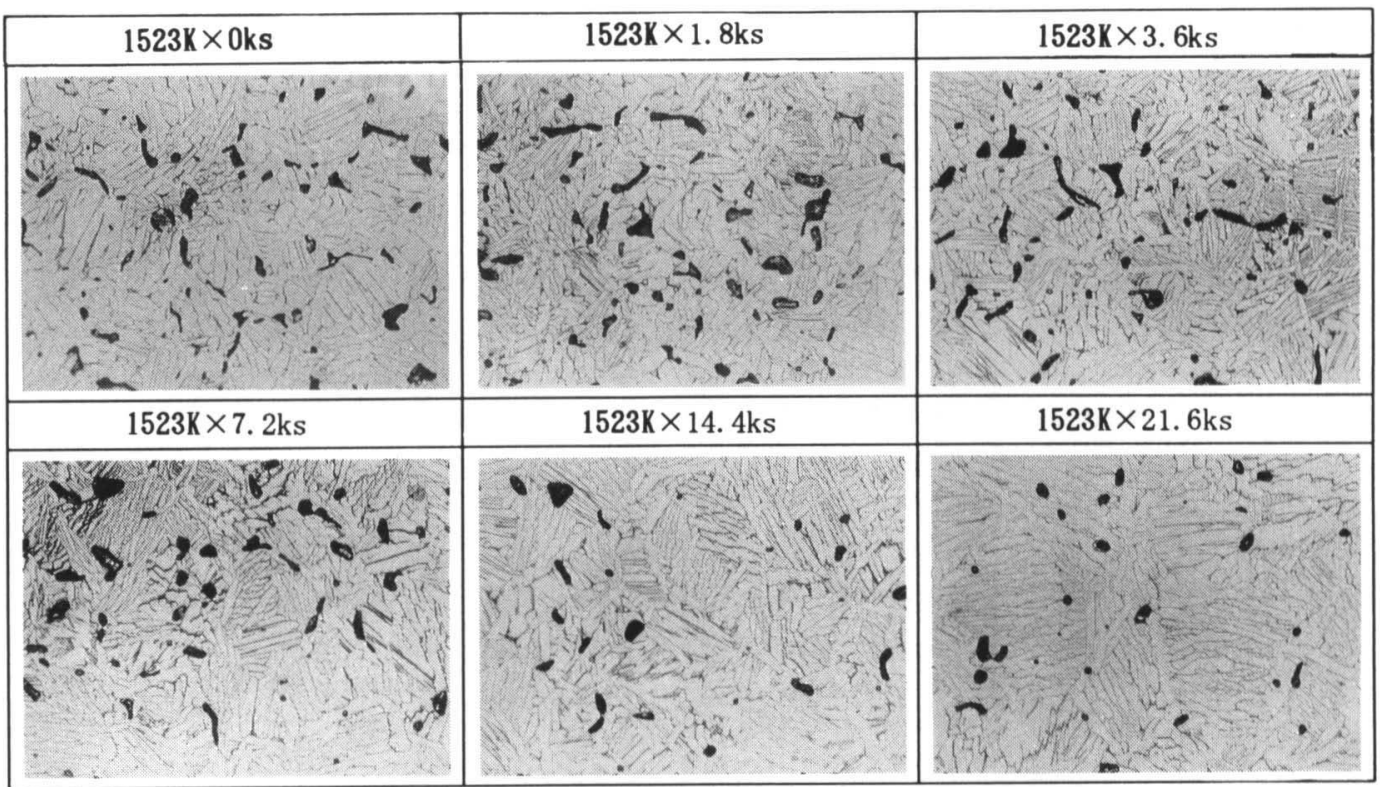

$100 \mu \mathbf{n}$

Photo. 2 Microstructures of sintered specimens.

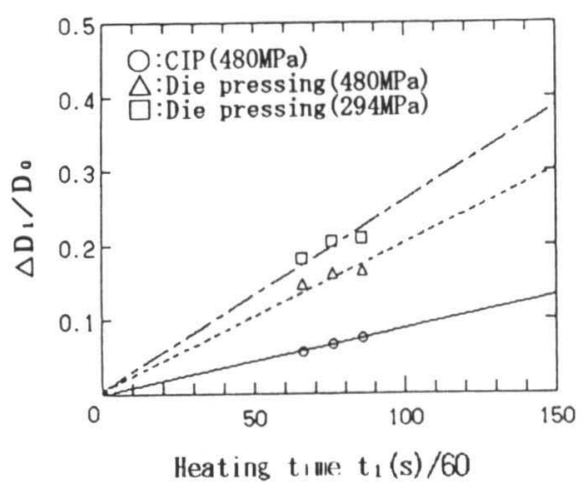

Fig. 2 Relationships betwen heating $t$ ime and relative density change.

$294 \mathrm{MPa}$ の場合にむほぼ同様の直線関係が得られている. これらの直線の傾きおよびび切片と焼結温度の関係を 調べることにより次式を得た.

$$
\begin{aligned}
\Delta_{2} / D_{0} & =\left(1.23 \times 10^{-6} \mathrm{~T}+5.21 \times 10^{-4}\right) \cdot\left(\mathrm{t}_{2} / 60\right)^{\mathrm{x}} \\
\mathrm{X} & =\left(2.43 \times 10^{-4} \mathrm{~T}+2.42 \times 10^{-1}\right)
\end{aligned}
$$

Fig.4には, 全データについて, 以上のようにして求 めた密度推定式による計算値と実測値の関係を示した。 相関はかなりよいと言える.

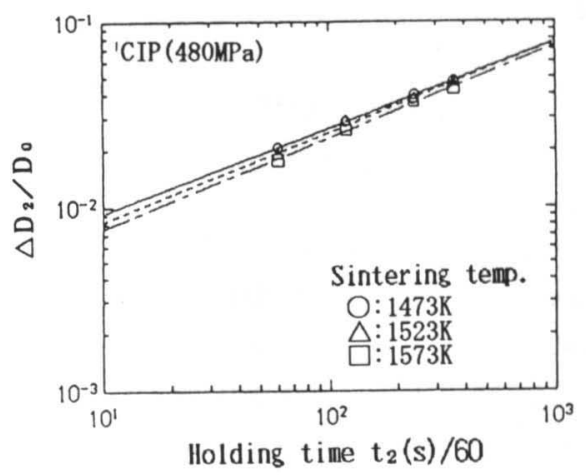

a) After CIP (48OMPa)

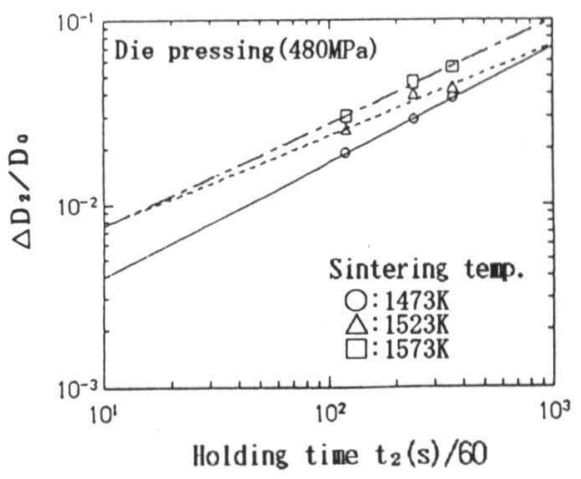

b) After die pressing (480Mpa)

Fig. 3 Relationships between holding time and relative density change (Isothermal range). 


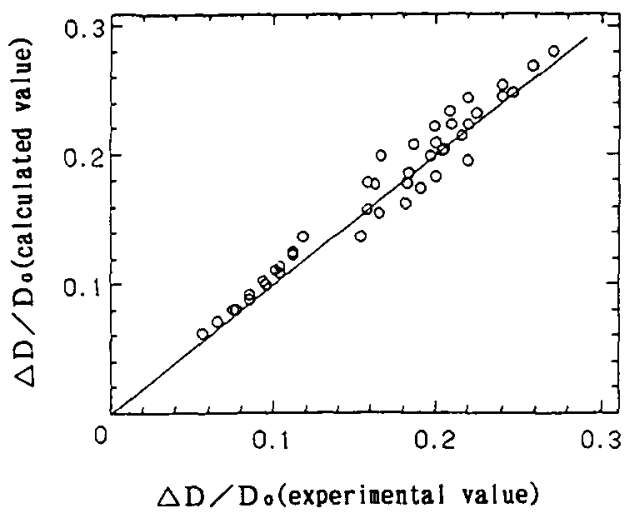

Fig.4 Correlation between calculated values and experimental values concerning increasing rate of density.

\section{3 角柱金型による焼結鑃造試駼}

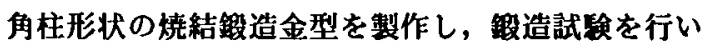
绕結体中の空攽の消減犾況や内部組織に対する各種鋠 造条件の影辢を調查した。

\section{1 実験方法}

鈠造試験で用いた金型の材質はJIS SKD61（熱間ダ イス鋼）で，金型の内寸法はFig.5に示したように愊 $16 \mathrm{mu}$, 高さ $20 \mathrm{~mm}$ 長さ100mいである. 金型内に埋め込ま れたヒータにより673Kまでの加熱が可能である．加圧 方法は上パンチによる片押しである.毂造後の試駼片 の取り出しは油圧シリンダーにより行う.

焼結試験片は前章で得られた結果により，CIP成形 圧 $480 \mathrm{MPa}$ ，焼結温度 $1523 \mathrm{~K}$ ，焼轺時間 $9 \mathrm{ks}$ の条件で作製 した．焼結体の相対密度(D)は97\%である．鈠造用の 武験片（プリフォーム）はこの焼結体をFig.5中に示 した 3 種類の寸法A，B，Cに機械加工したすのを用いた. 劉造時のメタルフローの程度はAが最む小さく，Cが最 む大きい。

これらの試験片を不活性察围気(Ar)中で1373Kに加 熟し, 所定の温度に達した媵0.9ks保持し, その後， 金型内に㨉入して解造した. 金型加熱温度は673K，耕 造荷重は $490 \mathrm{kN}$, 鎯造速度は50, 200 $\mathrm{m} / \mathrm{s} の 2$ 種類とし

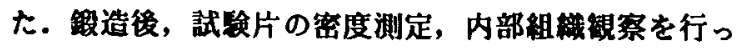
た.

\section{2 実臨轺果および考察}

加熱温度は1373Kであるか，加熱加抽出後加圧する までに約10s程度の時間を要した。この間に試険片の 表面湜度が低下し，热電対を用いた実测によれば政造

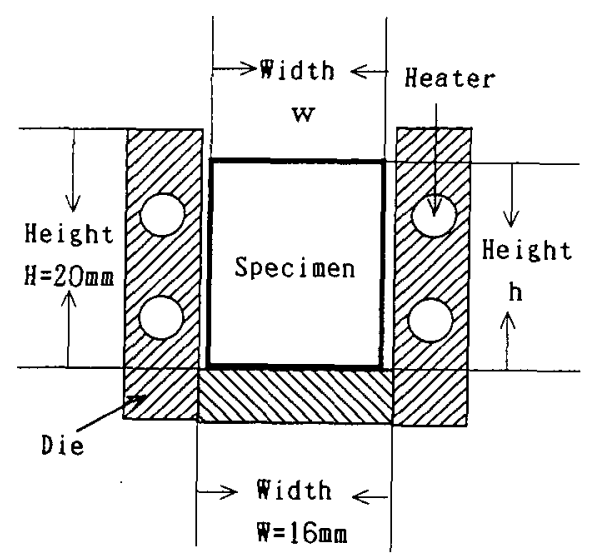

Inner length of die $L=100 \mathrm{~mm}$

Dimensions of specimen (mm)

\begin{tabular}{|c|cc|}
\hline & w & h \\
\hline A & 15.0 & 15.0 \\
B & 14.0 & 16.0 \\
C & 11.2 & 20.0 \\
\hline
\end{tabular}

Length of specimen $l=98.0 \mathrm{~mm}$

Fig.5 Dimensions of forging die and specimens

時には1273K近傍まで低下していた。

Photo.3に，鋮造後の内部組織におよぼす試験片形 状および鈠造速度の影響を示した。密度の測定結果も 同図中に示した．鍜造前の焼結体密度は $4.296 \mathrm{~g} / \mathrm{cm}^{3}$ で ある.すべての試験条件で毁造後の密度は增加し, 相 対密度ほぼ100\%となった。なお，真密度は $4.42 \mathrm{~g} / \mathrm{cm}^{3}$ である. 同一形状の試験片では鍜造速度が遅いほうが 組織の空陵量は隇少している。これは，本実験では鍛 造荷重を $490 \mathrm{kN}$ （圧縮応力：約 $300 \mathrm{MPa}$ ）一定にしてい

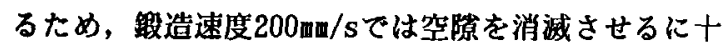
分な俯力が発生していなかったすのと解釈される。 た，同一の鉣造速度ではメタルフローが多くなる形状 のほうが空陧は少なくなった．今回の銀造条件ではい すれの場合も数值上は真密度に達しているが，空償が 認められないのはC形状の場合だけである.また，内 部租轿は加工により非常に微細になっている樣子がう かがる. Photo.4に上パンチ近傍の内部組織写真を 示したが焼結組織および空筫が残存しているのがわか る. 金型底面むほぼ同様の状況である。これは鍛造時 の試釱片表面の温度降下の影暗と考えられる。

以上の耛果から，焼結体中の空吵を消隇させるには， 


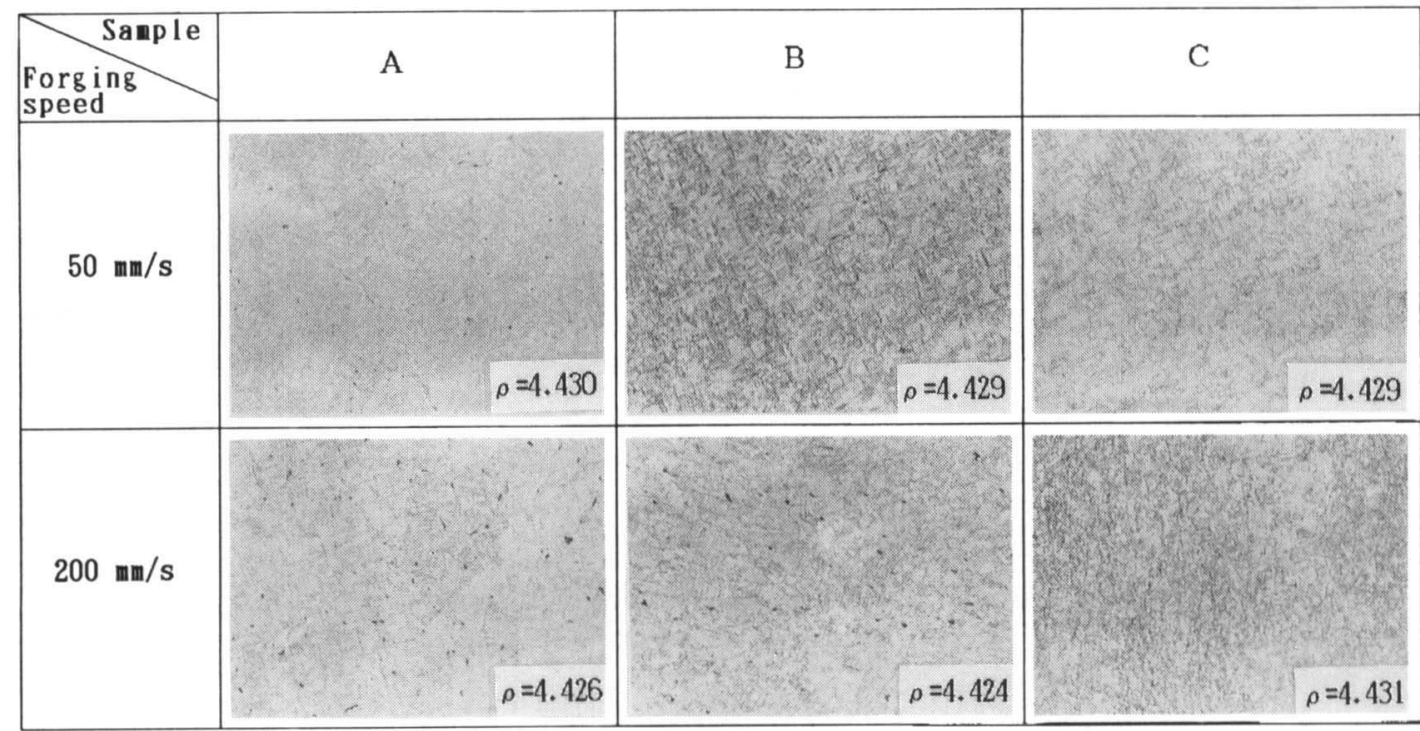

$100 \mu$ !

Photo. 3 Microstructure of specimens before and after forging (central part of the specimens).

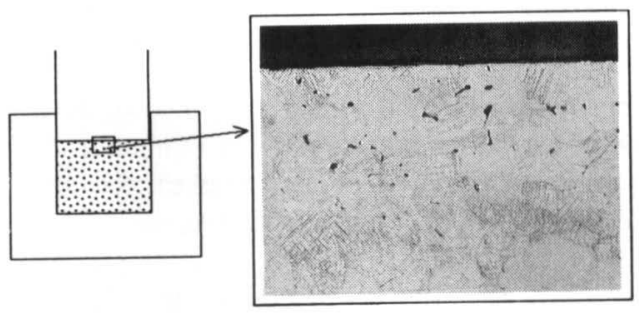

Photo. 4 Microstructure at the edge of the forged specimen.
（2）鍛造特性に関しては、1373K加熱、441MPaの圧縮応 力の条件で錪造後の相対密度はほぼ100\%となった。し かし、試験片の表面近傍に空隚が認められた。これは, 表層部の温度低下によるものと考えられる. 同一形状 の試験片では錪造速度が遅いほうが, 空隙の減少には 効果がある.また，同一の鈠造速度では鍜造により， メタルフローが多くなる形状の方が空隙は消滅しやす い.
鍛造荷重を高くすることと, メタルフローが多くなる 形状の素材を用いることが有効であることがわかる.

\section{4 結言}

素粉末混合法により製造したTi-6Al-4V焼䊅合金を鍜 造する焼結錪造法において, 鍛造用素材の適正な製造 条件を明らかにするために成形焼結条件を変化させて 焼結举動を調査した. また, 角柱形状金型を用いて鍜 造特性を調査した結果, 以下の事項が明らかになった. (1)成形焼結挙動に関しては, 同一成形圧力の場合, CIP成形体の密度の方が金型プレス成形体の密度より 約10\%高い. 成形体の密度が高いほど焼結体の密度も 高くなる．焼結による密度の增加率は恒温域よりも昇 温域の方が大きい,などが明らかになった。 また, 実 測値とよく一致する密度推定式（2），(3)，(4) を得ることができた.

\section{文献}

1 ) 新素材/新金属 最新製造・加工ハンドブック, 163 (工業資料センター) など.

2 ）萩原益夫, 河部義邦 : 鉄と鋼, 75(1989), 17.

3) D.Eylon, F.H.Froes: ASM Handbook, Volume 2, 647.

4) S. Abkowitz, D.M. Rowell : Prog. Powder Metal, No.42(1986), 611 .

5 ）萩原益夫, 海江田義也, 河部義邦, 三浦伸 : 鉄と 鋼, 76(1990), 124.

6 ) 山崎達夫, 藤井秀樹 : CAMP-ISIJ, 5(1992), 1804.

7 ）木村尚：塑性と加工, 34-386(1993), 232.

8 ）大槻真人，河野通：㸮体および粉末冶金, 37 (1990), 31.

9) 溙葉久吉, 三谷裕康: 粉末冶金学, コロナ社 (1978), 71. 